Quim. Nova, Vol. 35, No. 4, 818-821, 2012

\title{
SET-UP OF A METHOD USING LC-UV TO ASSAY MOMETASONE FUROATE IN PHARMACEUTICAL DOSAGE FORMS
}

\author{
Aline Ferreira Ourique, Renata Vidor Contri, Silvia Stanisçuaski Guterres e Ruy Carlos Ruver Beck* \\ Departamento de Produção e Controle de Medicamentos, Faculdade de Farmácia, Universidade Federal do Rio Grande do Sul, \\ Av. Ipiranga, 2752, 90610-000 Porto Alegre - RS, Brasil \\ Adriana Raffin Pohlmann \\ Departamento de Química Orgânica, Instituto de Química, Universidade Federal do Rio Grande do Sul, Av. Bento Gonçalves, \\ 9500, 91501-970 Porto Alegre - RS, Brasil
}

Ana Melero e Ulrich F. Schaefer

Department of Biopharmacy and Pharmaceutical Technology, Saarland University, Saarbrücken, Germany

Recebido em 19/7/11; aceito em 3/10/11; publicado na web em 4/1/12

\begin{abstract}
A reliable method using LC-UV to assay mometasone furoate (MF) in creams or nasal sprays using the same chromatographic conditions was set up. Methanol:water 80:20 (v/v) $\left(1.0 \mathrm{~mL} \mathrm{~min}^{-1}\right)$ was used as mobile phase. MF was detected at $248 \mathrm{~nm}$ and analyzed in a concentration range from 1.0 to $20.0 \mu \mathrm{g} \mathrm{mL}^{-1}$. The method provided acceptable theoretical plates, peak simmetry, peak tailing factor and peak resolution a short run $(5 \mathrm{~min})$. The method showed specificity, good linearity $(r=0.9999)$ and the quantification limit was $0.379 \mu \mathrm{g} \mathrm{mL}^{-1}$. Furthermore, the method was precise $(\mathrm{RSD}<2.0 \%)$, accurate (recovery $>97 \%$ ) and robust.
\end{abstract}

Keywords: pharmaceuticals; liquid chromatography; mometasone.

\section{INTRODUCTION}

Glucocorticoids are potent anti-inflammatory drugs for the treatment of allergic diseases such as asthma and allergic rhinitis. They act by reducing the number and the activation process of inflammatory cells in the airways. ${ }^{1,2}$ Mometasone furoate (MF) (Figure 1) is a synthetic 17-heterocyclic glucocorticoid currently available in cutaneous, nasal, and oral inhaled preparations. It presents high topical potency and affinity for the glucocorticoid receptors and a low risk of systemic absorption. ${ }^{3}$ Besides, it is a potent inhibitor of the in vitro production of three inflammatory cytokines: IL-1, IL-6, and TNF-alpha. MF is a highly lipophilic molecule due to its ester side chains, which facilitates its absorption through nasal mucosa and uptake across phospholipid cell membranes. ${ }^{4.5}$

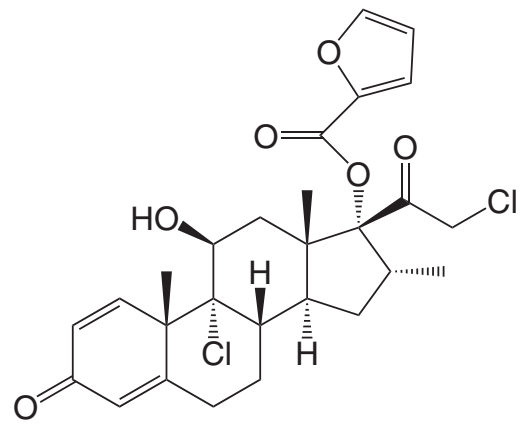

Figure 1. Chemical structure of mometasone furoate

Some techniques have been used to determine MF in different biological matrices. Studies reported the quantification of MF in human plasma using methods based on high performance liquid chromatography ${ }^{6,7}$ and by LC/MS/MS..$^{8,9}$ MF was also assayed by LC (liquid chromatography) in other biological matrices such as tissues and bronchoalveolar lavage fluid. ${ }^{10,11}$ In addition, some methods have

\footnotetext{
*e-mail: ruy.beck@ufrgs.br
}

been described to assay MF in new formulations such as in situ gel systems and nanoparticles ${ }^{5,12}$ (Table 1). The high performance liquid chromatography is a fast and useful technique and has been widely used in the validation of analytical methods for quantification of drugs in different pharmaceutical products. ${ }^{13-16}$

Regarding the official methods, British and United States Pharmacopoeias (BP 2008 ${ }^{17}$ and USP 2008, ${ }^{18}$ respectively) report methods to assay MF in pharmaceutical formulations by LC-UV, ${ }^{19}$ as showed in Table 1. However, BP methods employ iso-octane to extract the drug from the different samples, which is an expensive solvent compared to others widely used in analytical assays, like methanol and acetonitrile. In addition, USP methods are available only to assay MF in creams. ${ }^{18}$ Clearly, there is a lack of standardization of simple methods for the quantification of MF in creams and nasal spray under the same chromatographic conditions without using high temperatures or expensive extraction solvents.

Taking all these considerations into account, to the best of our knowledge, there has not been described a specific method to assay MF in creams or nasal sprays using a unique and simple liquid chromatography method with UV detection. This alternative could represent a useful tool for analysis in academic, official and/or private analytical laboratories, including the pharmaceutical industry, with a reduced analytical cost. So, the aim of the present work was to develop and validate a reliable method using LC-UV to assay mometasone furoate in creams as well as in nasal sprays, using simple conditions, including a widely used solvent in analytical assays (methanol), compared to the official methods currently available.

\section{EXPERIMENTAL}

\section{Reagents and materials}

Mometasone furoate reference substance (purity grade: $99.6 \%$ ) was obtained from Fagron (Barsbuettel, Germany). HPLC-grade methanol was acquired from Tedia (São Paulo, Brazil). The nasal spray containing mometasone furoate (Nasonex, Schering-Plough, $0.5 \mathrm{mg}$ 
Table 1. Method characteristics to assay mometasone furoate in different biological matrices, pharmaceuticals and drug delivery systems

\begin{tabular}{|c|c|c|c|c|c|}
\hline Sample & Technique* & Column* & Mobile Phase* & Wavelength & Ref. \\
\hline Human plasma & $\begin{array}{l}\text { LC-Photodiode-array } \\
\text { UV/VIS }\end{array}$ & $\begin{array}{l}\text { Ultrasphere octyl column } \\
(150 \text { x } 4.6 \mathrm{~mm} \text { ID, } 5 \mu \mathrm{m} \\
\text { particle size, Beckman, CA) }\end{array}$ & Methanol and water $(59: 41 \mathrm{v} / \mathrm{v})$ & $248 \mathrm{~nm}$ & 6 \\
\hline $\begin{array}{l}\text { Human plasma and } \\
\text { lung tissue }\end{array}$ & $\begin{array}{l}\text { LC-Dual wavelength } \\
\text { UV detector }\end{array}$ & $\begin{array}{l}\text { Symmetry } C_{18} \text { column }(150 \\
\text { x } 4.6 \text { mm ID, } 5 \mu \text { m particle } \\
\text { size, Waters, MA) }\end{array}$ & $\begin{array}{l}\text { Gradient elution using water (con- } \\
\text { taining } 0.2 \%(\mathrm{v} / \mathrm{v}) \text { acetic acid) and } \\
\text { acetonitrile, starting at } 60: 40(\mathrm{v} / \mathrm{v}) \\
\text { increasing linearly to } 29: 71(\mathrm{v} / \mathrm{v})\end{array}$ & $254 \mathrm{~nm}$ & 7,10 \\
\hline Human plasma & LC-MS/MS & $\begin{array}{l}\text { LC-18-DB }(3.3 \mathrm{~cm} \times 4.6 \\
\mathrm{mm}, 3 \mu \mathrm{m})\end{array}$ & $\begin{array}{l}\text { Methanol and ammonium acetate } \\
25 \mathrm{mM}(80: 20)\end{array}$ & $\begin{array}{ll}--- \\
-\cdots\end{array}$ & 1 \\
\hline Human plasma & LC-MS/MS & $\begin{array}{l}\text { Waters } 5 \mu \mathrm{m} \text { Symetry } \mathrm{C}_{18} \\
\text { column }(50 \times 4.6 \mathrm{~mm} \text { i.d., } \\
\text { Milford, MA) }\end{array}$ & Methanol and water $(85: 15 \mathrm{v} / \mathrm{v})$ & --- & 9 \\
\hline $\begin{array}{c}\text { Lung tissue, } \\
\text { bronchoalveolar lavage } \\
\text { and nanoparticles } \\
\end{array}$ & LC-UV & $\begin{array}{l}14 \mathrm{~cm} \text { Kromasil } \mathrm{C}_{18} 150-4.6 \\
(\text { Merck, Germany, particle } \\
\text { size } 5 \mu \mathrm{m})\end{array}$ & Methanol and water $(65: 35 \mathrm{v} / \mathrm{v})$ & $254 \mathrm{~nm}$ & 5,11 \\
\hline In situ gel & LC-UV & $\begin{array}{l}\text { Dikma DiamonsilTM } \mathrm{C}_{18} \\
\text { column }(5 \mu \mathrm{m}, 200 \times 4.6 \\
\mathrm{mm}) \text { at } 40^{\circ} \mathrm{C}\end{array}$ & Methanol and water $(75: 25 \mathrm{v} / \mathrm{v})$ & $254 \mathrm{~nm}$ & 12 \\
\hline Cream and nasal spray & LC-UV & $\begin{array}{l}\text { Hypersyl BDS C18 }(5 \mu \mathrm{m}, \\
100 \times 5.0 \mathrm{~mm}) \text { at } 60^{\circ} \mathrm{C}\end{array}$ & Methanol and water $(55: 45 \mathrm{v} / \mathrm{v})$ & $238 \mathrm{~nm}$ & 17 \\
\hline Cream & LC-UV & $\mathrm{C} 8(250 \mathrm{~mm} \times 4.6 \mathrm{~mm})$ & Methanol and water $(65: 35 \mathrm{v} / \mathrm{v})$ & $254 \mathrm{~nm}$ & 18 \\
\hline
\end{tabular}

*cited according to the original reference

of mometasone furoate per gram of suspension; excipients: microcrystalline cellulose, citric acid, glycerol, sodium citrate, polysorbate 80 , benzalkonium chloride, phenyl ethyl alcohol and water) and the cream containing mometasone furoate (Furoato de Mometasona, Eurofarma, $1 \mathrm{mg} \mathrm{g}^{-1}$ of mometasone furoate per gram of cream, excipients: auto-emulsifying wax, propylene glycol, methylparaben, propylparaben, disodium EDTA, phenoxyethanol, mineral oil, lanolin alcohol and water) were obtained from the market (Batches 9KTLDB9001 and $165440 \mathrm{~A}$, respectively). All other reagents were of pharmaceutical or HPLC grade and used as received.

\section{Instrumentation and chromatographic conditions}

The system consisted of an UV detector, pump and auto-injector S200 Perkin-Elmer (Perkin-Elmer, USA) and a Gemini RP-18 column (150 x $4.60 \mathrm{~mm}, 5 \mu \mathrm{m}$, Phenomenex, Torrance, USA). The mobile phase was composed of methanol and Milli-Q water 80:20 (v/v) pumped at an isocratic flow $\left(1.0 \mathrm{~mL} \mathrm{~min}^{-1}\right)$ at room temperature. The mobile phase was filtered through a $0.45 \mu$ m nylon membrane filter (Sartorius, Germany) and degassed before use. Chromatographic run was set to $5 \mathrm{~min}$. The volume injected was $20 \mu \mathrm{L}$ and mometasone furoate was detected at $248 \mathrm{~nm}$.

\section{Standard solution}

A stock standard solution $\left(0.5 \mathrm{mg} \mathrm{mL}^{-1}\right)$ was prepared by dissolving $25.0 \mathrm{mg} \mathrm{MF}$ in $50.0 \mathrm{~mL}$ of methanol. From this solution, a working standard of $10 \mu \mathrm{g} \mathrm{mL}^{-1}$ was prepared adding $200 \mu \mathrm{L}$ of the stock standard solution to a $10.0 \mathrm{~mL}$ volumetric flask, which was completed with methanol. In addition, the stock standard solution was diluted, as necessary, with methanol to give five different concentrations of MF (1.0, 5.0, 10.0, 15.0, and $\left.20.0 \mu \mathrm{g} \mathrm{mL}^{-1}\right)$, which were used in the linearity study. All solutions were filtered (Sartorius Biolab Products $0.45 \mu \mathrm{m})$ before injected $(n=3)$ into the LC system.

\section{Sample preparation}

An amount of cream (claimed to have $1 \mathrm{mg} \mathrm{g}^{-1}$ of MF) and nasal spray (claimed to have $0.5 \mathrm{mg} \mathrm{g}^{-1}$ of MF) equivalent to $0.5 \mathrm{mg} \mathrm{mL}^{-1}$ of
MF was transferred to a 50 and $10 \mathrm{~mL}$ volumetric flask, respectively ( $\mathrm{n}=3$, for each dosage form). Methanol was added to each flask in order to extract the drug. Afterwards, the samples obtained from the cream were submitted to ultrasound for $30 \mathrm{~min}$, their volume were completed with methanol and then they were centrifuged for $5 \mathrm{~min}$ at $4200 \mathrm{~g}$ (Sigma Laboratory Centrifuges $4 \mathrm{~K} \mathrm{15}$, Germany). The samples obtained from the nasal spray were first subjected to magnetic stirring (10 $\mathrm{min}$ ) and afterwards to ultrasound (10 $\mathrm{min})$, their volume were completed with methanol and finally they were centrifuged for 5 min at $4200 \mathrm{~g}$ (Sigma Laboratory Centrifuges 4K 15, Germany). All samples were filtered through a membrane filter (Sartorius Biolab Products $0.45 \mu \mathrm{m}$ ) prior LC analysis. All samples were prepared to have a final concentration of $10 \mu \mathrm{g} \mathrm{mL}^{-1}$ of the drug.

\section{Method validation}

The optimized chromatographic conditions were validated by evaluating specificity, linearity, precision, accuracy, robustness and detection and quantification limits, which are the parameters indicated in the guidelines of the International Conference on Harmonization (ICH). ${ }^{20}$ Besides, theoretical plates, peak symmetry, tailing factor, retention factor and resolution in relation to the cream excipient peak were calculated according to official guidelines. ${ }^{17,18,20}$

\section{Specificity}

In order to evaluate the possible interferences from the excipients, sample solutions obtained from the cream and the nasal spray (obtained according to section Sample preparation) were evaluated by multi-wavelenght scanning (DAD detector). The system used consisted of a Shimadzu liquid chromatographic system (Shimadzu, Tokyo, Japan) equipped with a LC-10ADVP pump multichannel solvent delivery coupled to a SIL-10ADVP auto-sampler and a SPDM10AVP photodiode array detection (DAD) for multi-wavelength scanning.

\section{Linearity}

The analytical curves $(n=3)$ were obtained with five concentrations of the reference solution in the range of $1-20 \mu \mathrm{gL}^{-1}$. Three 
independent calibration curves were plotted and linearity was evaluated by linear regression analysis by the least-square regression method, which was used to calculate the correlation coefficient, $y$-intercept and slope of the regression line. Detection (LOD) and quantification (LOQ) limits were determined directly from the calibration plot, according to the equations indicated in the ICH guidelines. ${ }^{20}$

\section{Precision}

The precision of the method was determined by repeatability (intra-day precision) and intermediate precision (inter-day precision) for each dosage form. Repeatability (intra-day precision) was evaluated by measuring, in triplicate, six different samples of the same concentration $\left(10.0 \mu \mathrm{g} \mathrm{mL}^{-1}\right)$ under the same experimental conditions and at the same day. Intermediate precision (inter-day precision) was calculated from the results obtained by the analysis of samples with the same concentration $\left(10.0 \mu \mathrm{g} \mathrm{mL}^{-1}\right)$ on three different days. Precision (repeatability and intermediate precision) was expressed as relative standard deviation (RSD\%).

\section{Accuracy}

Accuracy was evaluated assaying, in triplicate, different samples of each dosage form of known concentration $\left(5.0 \mu \mathrm{g} \mathrm{mL}^{-1}\right)$ spiked with three different concentrations of standard solution $(2.5,5.0$ and $7.5 \mu \mathrm{g} \mathrm{mL}^{-1}$ ), giving sample solutions corresponding to 7.5, 10.0 and $12.5 \mu \mathrm{g} \mathrm{mL} \mathrm{m}^{-1}$. The accuracy was calculated as the percentage of drug recovered from the formulations and expressed as the relative standard deviation $(\mathrm{RSD} \%)$ between the replicates $(n=3)$.

\section{Robustness}

The robustness was studied by evaluating the effect of small but deliberate variations in the chromatographic conditions. The conditions evaluated were the flow rate $\left( \pm 0.1 \mathrm{~mL} \mathrm{~min}{ }^{-1}\right)$, composition of mobile phase (methanol $\pm 5.0 \%$ ), wavelength $( \pm 4.0 \mathrm{~nm})$ and $\mathrm{LC}$ apparatus: A (serial number: 292N6102304A) and B (serial number: 293N6101601A). Sample solutions $(n=3)$ were evaluated for each variation of the conditions.

\section{RESULTS AND DISCUSSION}

LC-UV has been widely applied in pharmaceutical analysis, including drug assay in different pharmaceutical dosage forms. In this work, we evaluated the feasibility of developing a simple method using LC-UV to assay MF in creams as well as in nasal spray, using the same chromatographic conditions. This approach facilitates the routine analysis in academic, private, public and/or official analytical laboratories. Afterwards, the proposed analytical method was carefully validated to demonstrate its suitability. First, the maximum absorption wavelength of the reference drug solution was evaluated. The absorbance at $248 \mathrm{~nm}$ was chosen for our method considering the maximum absorption intensity. This result is in accordance with the literature. ${ }^{6}$

Figure 2 shows the chromatograms obtained from the standard methanol solution (Figure 2a), the sample solution from the nasal spray (Figure 2b) and the sample solution from the cream (Figure 2c) under the developed LC-UV conditions. Retention time of MF was around $4 \mathrm{~min}$, which enables a faster analysis compared with the BP method (described retention time around $9 \mathrm{~min}$ ). ${ }^{17}$ The chromatogram obtained from the cream present also other peaks, which are probably related to the formulation excipients.

The method provided acceptable theoretical plates $(\mathrm{N}=3,437)$, an
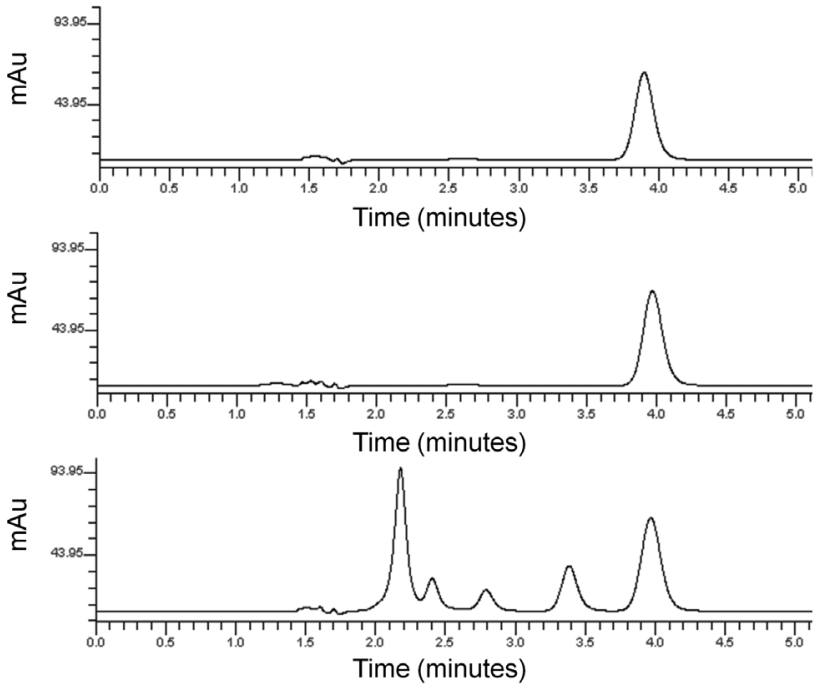

Figure 2. Chromatograms obtained from (a) methanolic standard solution, (b) sample solution from nasal spray and (c) sample solution from cream

excellent peak simmetry of 1.04 , a suitable peak tailing factor of 1.75 and an adequate retention factor $\left(\mathrm{K}^{\prime}=1.60\right)$ in a short run. The MF peak resolution in relation to the closest excipient peak was found to be 1.75 , which corresponds to an acceptable value. All the chromatographic parameters calculated were in accordance with reference values. ${ }^{21}$ Furthermore, PDA analysis showed a peak purity of $100 \%$, indicating that the other components of both formulations do not interfere in the MF assay, demonstrating the specificity of the proposed method.

The analytical curves for MF were constructed by plotting concentration versus peak area. A good linearity was observed in the range between 1 and $20 \mu \mathrm{gL}^{-1}$. The linear equation $(y=54394 x$ - 413.8) obtained by the least-square method $(\mathrm{n}=3)$ showed an adequate correlation coefficient $(r=0.9999)$.

The validity of the assay was verified by the analysis of variance. This statistical analysis revealed that the regression equation was linear $(\mathrm{F}$ calculated $=30290>\mathrm{F}$ critical $=4.96, \mathrm{p} \leq 0.05)$ with no linearity deviation $(\mathrm{F}$ calculated $=0.55<\mathrm{F}$ critical $=3.71 ; \mathrm{p}>0.05)$. LOD and LOQ were 0.125 and $0.379 \mu \mathrm{gL}^{-1}$, respectively. These low values indicate a good sensitivity of the proposed method.

The results obtained for precision are presented in Table 2. All RSD values were lower than $2.0 \%$, indicating good intra-day and

Table 2. Repeatability (intra-day) and intermediate precision (inter-day) of the method to assay MF in the cream and the nasal spray (sample solutions at a theoretical concentration of $10.0 \mu \mathrm{g} \mathrm{mL}-1$ )

\begin{tabular}{cccc}
\hline Dosage form & Parameter & $n$ & RSD (\%) \\
\hline Cream & Intra-day & 6 & 1.19 \\
& Inter-day & & \\
& Day 1 & 3 & 0.46 \\
Day 2 & 3 & 1.18 \\
Day 3 & 3 & 0.41 \\
& Day 1+2+3 & 9 & 1.49 \\
& Intra-day & & 1.46 \\
& Inter-day & 6 & 0.31 \\
& Day 1 & & 0.60 \\
& Day 2 & 3 & 0.84 \\
& Day 3 & 3 & 2.03 \\
\hline
\end{tabular}


Table 3. Accuracy of the method to assay MF in cream and nasal spray

\begin{tabular}{|c|c|c|c|c|}
\hline & Added $\left(\mu \mathrm{g} \mathrm{mL}^{-1}\right)$ & Found $\left(\mu \mathrm{g} \mathrm{mL}^{-1}\right)$ & Recovery (\%) & $\operatorname{RSD}(\%)$ \\
\hline \multirow[t]{4}{*}{ Cream } & 2.5 & $2.46 \pm 0.13$ & $99.32 \pm 2.26$ & 2.27 \\
\hline & 5.0 & $4.74 \pm 0.26$ & $95.44 \pm 4.66$ & 4.88 \\
\hline & 7.5 & $7.40 \pm 0.03$ & $98.18 \pm 0.53$ & 0.54 \\
\hline & & Mean & $97.64 \pm 1.99$ & 2.56 \\
\hline \multirow[t]{4}{*}{ Nasal spray } & 2.5 & $2.69 \pm 0.22$ & $103.74 \pm 4.18$ & 4.03 \\
\hline & 5.0 & $4.84 \pm 0.36$ & $97.02 \pm 6.83$ & 7.03 \\
\hline & 7.5 & $7.18 \pm 0.22$ & $93.88 \pm 4.18$ & 4.45 \\
\hline & & Mean & $98.21 \pm 5.04$ & 5.17 \\
\hline
\end{tabular}

inter-day precision. Regarding the accuracy evaluation, good recoveries were found as shown in Table 3 . The percentage of recovery indicated good accuracy and, consequentially, an agreement between the theoretical and the real concentration values.

Regarding the evaluation of robustness, the deliberate variation of the method conditions had no significant effect on assay data $(\mathrm{p}>$ 0.05 ) or on the chromatographic performance, indicating the robustness of the method in terms of small variation in the proportion of components of the mobile phase, in the detection wavelength, in the flow rate or even using a different apparatus (Table 4).

Table 4. Results from the robustness of the method to assay MF in cream and nasal spray

\begin{tabular}{ccc}
\hline Conditions & $\begin{array}{c}\text { \% Mometasone } \\
\text { Nasal Spray }\end{array}$ & $\begin{array}{c}\text { \% Mometasone } \\
\text { Cream }\end{array}$ \\
\hline Recommended conditions * & $101.65 \pm 1.71$ & $109.41 \pm 0.40$ \\
Mobile phase (methanol-water) & & \\
$75: 25$ & $102.53 \pm 1.81$ & $107.16 \pm 0.52$ \\
$85: 15$ & $100.02 \pm 2.92$ & $109.44 \pm 0.85$ \\
$\lambda(\mathrm{nm})$ & & \\
244 & $102.12 \pm 1.95$ & $110.47 \pm 1.49$ \\
252 & $101.71 \pm 2.01$ & $109.26 \pm 1.03$ \\
Flow rate (mL min $\left.^{-1}\right)$ & & \\
0.9 & $101.90 \pm 1.66$ & $110.33 \pm 1.16$ \\
1.1 & $101.81 \pm 1.77$ & $109.23 \pm 0.67$ \\
Apparatus & & \\
LC B & $102.22 \pm 1.84$ & $111.16 \pm 0.95$ \\
\hline
\end{tabular}

"The recommended conditions were: Gemini RP- 18 column $(150$ x $4.60 \mathrm{~mm}$, $5 \mu \mathrm{m})$ with methanol-water $80: 20(\mathrm{v} / \mathrm{v})$, as mobile phase at a flow rate $=1$ $\mathrm{mL} \min ^{-1}$, LC A equipment and UV detection at $248 \mathrm{~nm}$.

\section{CONCLUSIONS}

A rapid, simple, reliable, specific, linear, precise, accurate and robust method using LC-UV was developed and validated to assay mometasone furoate in different dosage forms, creams and nasal spray formulations, using the same LC conditions in a concentration ranged from 1.0 to $20.0 \mu \mathrm{g} \mathrm{mL}{ }^{-1}$. Furthermore, the method proposes a cheaper extraction procedure, avoiding the use of iso-octane as well as using simple chromatographic conditions, as room temperature instead of high temperatures as $60{ }^{\circ} \mathrm{C}$. This method represents a suitable alternative to assay MF compared to the currently available official methods, easily applied to routine analysis in laboratories of quality control of medicines.

\section{ACKNOWLEDGMENTS}

A. F. Ourique and R. V. Contri thank CAPES and CNPq for their fellowships, respectively. The authors thank the financial support of CNPq/Brazil, CAPES/Brazil, FAPERGS and INCT_if/CNPq. The project BMBF BRA 09/017 is thanked for the financial support.

\section{REFERENCES}

1. Affrime, M. B.; Cuss, F.; Padhi, D.; Wirth, M.; Pai, S.; Clement, R. P.; Lim, J.; Kantesaria, B.; Alton, K.; Cayen, M. N.; J. Clin. Pharmacol. 2000, 40, 1227.

2. Zhang, X.; Moilanen, E.; Adcock, I. M.; Lindsay, M. A.; Kankaanranta, H.; Life Sci. 2002, 71, 1523.

3. Crim, C.; Pierre, L. N.; Daley-Yates, P. T.; Clin. Ther. 2001, 23, 1339.

4. Derendorf, H.; Meltzer, E. O.; Allergy 2008, 63, 1292.

5. Surti, N.; Naik, S.; Bagchi, T.; Dwarkanath, B. S.; Misra, A.; AAPS Pharmsci. 2008, 9, 217.

6. Teng, X. W.; Foe, K.; Brown, K. F.; Cutler, D. J.; Davies, N. M.; J. Pharmaceut. Biomed. 2001, 26, 313.

7. Valotis, A.; Neukam, K.; Elert, O.; Hogger, P.; J. Pharm. Sci. 2004, 93, 1337.

8. Affrime, M. B.; Kosoglou, T.; Thonoor, C. M.; Flannery, B. E.; Herron, J. M.; Chest 2000, 118, 1538 .

9. Sahasranaman, S.; Tang, Y.; Biniasz, D.; Hochhaus, G.; J. Chomatogr., B: Anal. Technol. Biomed. Life Sci. 2005, 819, 175.

10. Valotis, A.; Hogger, P.; Resp. Res. 2004, $5,7$.

11. Surti, N.; Naik, S.; Misra, A.; Sci. Pharm. 2009, 77, 123.

12. Cao, S.; Ren, X.; Zhang, Q.; Chen, E.; Xu, F.; Chen, J.; Liu, L.; Jiang, X.; Int. J. Pharm. 2009, 365, 109.

13. Cazedey, E. C. L.; Azevedo, R. C. P.; Silva, E. F.; Araújo, M. B.; Quim. Nova 2007, 30, 774 .

14. Fontana, M. C.; Hurtado, F. K.; Wrasse, M.; Boligon, A. A.; Venturini, T. P.; Rolim, C. M. B.; Beck, R. C. R.; Quim. Nova 2010, 33, 208.

15. Isler, A. C.; Lopes, G. C.; Cardoso, M. L. C.; Mello, J. C. P.; Quim. Nova 2010, 33, 1126.

16. Tagliari, M. P.; Kuminek, G.; Borgmann, S. H. M.; Bertol, C. D.; Cardoso, S. G.; Quim. Nova 2010, 33, 1790.

17. British Pharmacopeia; $5^{\text {th }}$ ed., United Kingdom: London, 2008.

18. The United States Pharmacopeia/The National Formulary; $31^{\text {th }}$ ed., Pharmacopoeial Convention: Rockville, 2008.

19. Görög, S.; J. Pharmaceut. Biomed. 2011, 55, 728.

20. ICH - Harmonised Tripartity Guideline; Validation of Analytical Procedures: Text and Methodology Q2 (R1). IFPMA: Geneva, 2005.

21. Lindsay, S.; High performance liquid chromatography, $2^{\text {nd }}$ ed., Wiley: New York, 1992. 